\title{
and EAST JAVA ECONOMIC JOURNAL

\section{EAST JAVA HALAL TOURISM OUTLOOK: POTENTIAL ANALYSIS AND STRATEGY FOR EAST JAVA HALAL TOURISM DEVELOPMENT}

\author{
Muhammad Mufli ${ }^{*}$
}

${ }^{1}$ Universitas Brawijaya, Indonesia

\begin{abstract}
East Java is included in the strategic area of national halal tourism development by the Ministry of Tourism. This was supported by the existence of religious tourism objects, natural and artificial tourism attractions, organizing annual cultural events, and adequate infrastructure. The purpose of this research is to review the potential and formulate strategies for the development of halal tourism in East Java. This research uses secondary data with qualitative method and SWOT analysis technique. Internal analysis shows the strengths and weaknesses factor as well as external analysis shows the opportunity and challenge factors of weakness in the development of halal tourism in East Java. Strength factors include diversity of tourist destinations, infrastructure to support the mobility of tourists, and level of tourist visits. Weakness factors include promotion and branding, skilled human resources, as well as supporting facilities for halal tourism. Opportunity factors include government policy support, existence of supporting institutions and international reputation of halal tourism Indonesia. Threat factors include economic stability, security stability and competition for the halal tourism industry. Based on the analysis of internal and external factors, the formulation of the development strategy of halal tourism in East Java among others : a) S-O strategy: encouraging domestic and foreign investment in the development of halal tourism in East Java; b) W-O strategy: development of East Java halal tourism information center platform; c) S-T strategy: : create a brand identity for East Java halal tourism titled "Khazanah Jawa Timur"; d) W-T strategy: establishment of special economic zone for east java halal tourism.
\end{abstract}

\author{
*Korespondensi: \\ Muhammad Mufli \\ E-mail: \\ mufli.ub@gmail.com
}

\section{ABSTRAK}

Jawa Timur masuk dalam kawasan strategis pengembangan wisata halal nasional oleh Kementerian Pariwisata. Hal ini didukung dengan keberadaan objek wisata religi, atraksi wisata alam dan buatan, penyelenggaraan event budaya tahunan, dan infrastruktur yang memadai. Tujuan dari penelitian ini adalah untuk mengkaji potensi dan merumuskan strategi pengembangan wisata halal di Jawa Timur. Penelitian ini menggunakan data sekunder dengan metode kualitatif dan teknik analisis SWOT. Analisis internal menunjukkan faktor kekuatan dan kelemahan serta analisis eksternal menunjukkan faktor peluang dan tantangan kelemahan dalam pengembangan wisata halal di Jawa Timur. Faktor kekuatan meliputi keragaman destinasi wisata, infrastruktur untuk mendukung mobilitas wisatawan, dan tingkat kunjungan wisatawan. Faktor kelemahannya antara lain promosi dan branding, sumber daya manusia yang terampil, serta fasilitas penunjang wisata halal. Faktor peluang antara lain dukungan kebijakan pemerintah, keberadaan lembaga pendukung dan reputasi internasional pariwisata halal Indonesia. Faktor ancaman antara lain stabilitas ekonomi, stabilitas keamanan dan persaingan industri pariwisata halal. Berdasarkan analisis faktor internal dan eksternal, maka rumusan strategi pengembangan wisata halal di Jawa Timur antara lain: a L strategi S-O: mendorong penanaman modal dalam

East Java Economic Journal, p-ISSN: 2597-8780, DOI: 10.53572/ejavec.v2i2.19 Open access undera Creative Commons Attribution- 4.0 
dan luar negeri dalam pengembangan wisata halal di Jawa Timur; b) strategi W-O: pengembangan platform pusat informasi pariwisata halal Jawa Timur; c) Strategi S-T: : menciptakan brand identity untuk wisata halal Jawa Timur bertajuk "Khazanah Jawa Timur"; d) Strategi W-T: pembentukan kawasan ekonomi khusus pariwisata halal Jawa Timur.

Keywords: Tourism, Halal Tourism, SWOT, East Java

JEL Classification: Z12, Z31, Z32, Z38

\section{Pendahuluan}

Pariwisata merupakan salah satu sektor jasa yang penting dalam perekonomian suatu negara. Menurut data The World Tourism Organization (UNWTO) dan The World Travel \& Tourism Council (WTTC) tahun 2016, sektor pariwisata memberikan kontribusi sebesar $10 \%$ Produk Domestik Bruto (PDB) global, kontribusi terhadap total ekspor dunia sebesar US\$7,58 triliun, foreign exchange earning sektor pariwisata tumbuh $25,1 \%$, dan pariwisata membuka lapangan kerja yang luas dimana 1 dari 11 lapangan kerja ada di sektor pariwisata. Indonesia merupakan negara yang bergantung pada sektor pariwisata dalam mendorong pertumbuhan ekonomi. Pada tahun 2016, kontribusi pariwisata terhadap PDB Nasional diproyeksikan sebesar empat persen atau sekitar Rp155 triliun dan menciptakan lapangan kerja untuk 11,3 juta orang (BPS, 2016).

Besarnya potensi pariwisata Indonesia semakin ditunjukkan dengan jumlah kedatangan wisatawan mancanegara dan domestik yang kian meningkat setiap tahunnya. Berdasarkan data Badan Pusat Statistik (BPS) tahun 2016, jumlah kedatangan wisatawan mancanegara ke Indonesia pada tahun 2011 mencapai 7.64 juta orang. Tahun 2016, pemerintah melalui Kementerian Pariwisata menargetkan kunjungan wisatawan mancanegara sebanyak 12 juta orang. Target tersebut tercapai di akhir tahun 2016, dan tahun 2017 pemerintah menargetkan kunjungan wisatawan asing 15 juta orang. Jumlah kunjungan wisatawan domestik tahun 2013 mencapai 250.036 .370 orang, tahun 2014 sedikit meningkat menjadi 251.200.000 orang, tahun 2015 naik menjadi 255.050 .000 orang dan di tahun 2016 sebanyak 263.000 .000 orang. Selain penetapan target kunjungan wisatawan asing dan nusantara, Kementerian Pariwisata RI mulai mengembangkan sebuah konsep pariwisata halal sebagai daya dukung Rencana Strategis Kementerian Pariwisata Tahun 2015-2019.

Pengembangan wisata halal oleh pemerintah didasarkan pada potensi kunjungan wisata halal itu sendiri. Studi dari MasterCard \& Crescent Rating dalam Global Muslim Travel Index tahun 2016, pasar wisata halal akan menjadi salah satu segmen yang paling cepat berkembang di industri pariwisata global. Pada 2015, diperkirakan jumlah wisatawan muslim global mencapai 117 juta dan diproyeksikan akan tumbuh menjadi 168 juta pada 2020, dimana pengeluaran wisata oleh wisatawan muslim diperkirakan akan melebihi USD 200 miliar. Perkembangan wisata halal juga dipengaruhi oleh demand yang terus meningkat seiring dengan pertambahan jumlah populasi muslim di dunia. Berdasarkan data dari World Muslim Population pada tahun 2014, jumlah populasi muslim di dunia mencapai 2,38 miliar jiwa atau setara dengan $28,26 \%$ dari total populasi di dunia.

Kementerian Pariwisata telah menetapkan 13 provinsi sebagai destinasi wisata halal unggulan, yaitu Nusa Tenggara Barat (NTB), Nangroe Aceh Darussalam, Sumatera Barat, Riau, Lampung, Banten, DKI Jakarta, Jawa Barat, Jawa Tengah, Yogyakarta, Jawa Timur, Sulawesi Selatan, dan Bali (Andriani, 2015). Penetapan 13 provinsi tersebut merupakan salah satu langkah strategis pemerintah melalui Kementerian Pariwisata dalam mempercepat Indonesia menjadi kiblat pariwisata halal dunia. Salah satu provinsi yang berpeluang dalam mendukung program percepatan Indonesia menjadi kiblat pariwisata halal dunia adalah Provinsi Jawa Timur. Jawa Timur merupakan salah satu provinsi di Indonesia dengan keragaman budaya, wisata sejarah dan wisata alam yang menarik untuk dikunjungi oleh wisatawan. Sektor pariwisata menjadi salah satu sektor unggulan Provinsi Jawa Timur dalam penopang pertumbuhan ekonomi daerah (BAPPENAS, 2015). Provinsi Jawa Timur merupakan kawasan strategis dalam pengembangan pariwisata nasional karena berada pada jalur perjalanan pariwisa- 
ta nasional (Lembayun, 2012). Pada tahun 2016, Kementerian Pariwisata juga menetapkan Provinsi Jawa Timur sebagai 10 prioritas pengembangan destinasi pariwisata unggulan Indonesia melalui Bromo-Tengger Semeru. Kawasan wisata Bromo-Tengger-Semeru berada di tiga kabupaten di Jawa Timur yaitu Kabupaten Malang, Kabupaten Pasuruan dan Kabupaten Probolinggo (Ratman, 2016).

Tabel 1. Data Kunjungan Wisatawan Domestik, Mancanegara dan PDRB Sektor Pariwisata Provinsi Jawa Timur

\begin{tabular}{|c|c|c|c|}
\hline \multirow[t]{2}{*}{ Tahun } & \multicolumn{2}{|c|}{ Kunjungan Wisatawan } & \multirow[t]{2}{*}{ PDRB } \\
\hline & Domestik & Mancanegara & \\
\hline 2012 & 33,2 juta orang & 263.943 orang & Rp 75,61 Triliun \\
\hline 2013 & 39,68 juta orang & 300.909 orang & Rp 88,16 Triliun \\
\hline 2014 & 45,6 juta orang & 463.193 orang & Rp 101,9 Trilun \\
\hline 2015 & 51,46 juta orang & 612.412 orang & Rp 92,68 Trilun \\
\hline 2016 & 55,0 juta orang & 618.536 orang & Rp 106,27 Triliun \\
\hline
\end{tabular}

Sumber: BPS Provinsi Jawa Timur (Data diolah)

Setiap tahun jumlah wisatawan domestik yang berkunjung ke Jawa Timur terus mengalami peningkatan. Hal serupa juga terlihat pada tingkat kunjungan wisatawan mancanegara. Sepanjang tahun 2012 hingga 2016 jumlah kunjungan wisatawan mancanegara di Jawa Timur cenderung meningkat. Keberadaan kunjungan wisatawan domestik dan mancanegara di Provinsi Jawa Timur menyebabkan sektor pariwisata menjadi salah satu sektor penggerak pertumbuhan ekonomi regional. Berdasarkan data BPS Provinsi Jawa Timur Tahun 2016, kontribusi pariwisata terhadap perekonomian Jawa Timur selama rentang tahun 2012-2016 mengalami peningkatan. Pada tahun 2012, kontribusi PDRB pariwisata mencapai Rp75,61 triliun yang selanjutnya meningkat pada tahun 2013 dan 2014 masing-masing menjadi Rp88,16 triliun dan Rp101,9 triliun. Tahun 2015 PDRB pariwisata mengalami sempat mengalami penurunan menjadi Rp92,68 triliun, namun pada tahun 2016 meningkat lagi menjadi Rp106,27 triliun.

Pengembangan pariwisata Jawa Timur mulai mengarah pada konsep pariwisata halal setelah ditetapkan sebagai 13 provinsi pengembangan destinasi wisata halal unggulan oleh Kementerian Pariwisata pada tahun 2015. Potensi pengembangan pariwisata halal di Provinsi Jawa Timur antara lain didukung oleh faktor-faktor: 1) Dominasi populasi muslim di Jawa Timur; 2) Keragaman budaya, dimana Provinsi Jawa Timur dikenal sebagai daerah yang kental dengan kebudayaan muslim, di samping warisan sejarah perkembangan Islam nusantara yang terpusat di Jawa Timur melalui Wali Songo; 3) Keberadaan objek wisata religi mulai bangunan masjid bersejarah serta tempat ziarah tokoh-tokoh penyebar muslim di Jawa Timur maupun objek wisata alam seperti pantai, permandian, serta penyelenggaraan festival budaya; 4) Akomodasi dan layanan lain yang diperlukan oleh wisatawan seperti hotel-hotel, restoran atau rumah makan yang telah ber sertifikasi halal serta ketersediaan fasilitas lembaga keuangan syariah, rumah sakit Islam.

\section{Tinjauan Pustaka}

\section{Tinjauan Industri Pariwisata}

Industri pariwisata adalah kumpulan usaha pariwisata yang saling terkait dalam menghasilkan barang atau jasa bagi pemenuhan kebutuhan wisatawan pada penyelenggaraan pariwisata (Ismayanti, 2010). Menurut Spilane dalam Subagyo (2012), pariwisata adalah perjalanan dari satu tempat ke tempat yang lain, bersifat sementara, dilakukan perorangan maupun kelompok, sebagai usaha mencari keseimbangan, keserasian atau kebahagiaan dengan lingkungan hidup dalam dimensi sosial, budaya, alam dan ilmu. 
Menurut Rani (2014), pariwisata adalah suatu aktivitas yang kompleks, yang dapat dipandang sebagai suatu sistem yang besar, yang mempunyai berbagai komponen seperti ekonomi, politik, sosial, budaya, dan seterusnya. Dalam sistem pariwisata, ada banyak aktor yang berperan dalam menggerakkan sistem. Aktor tersebut adalah insan-insan pariwisata yang ada pada berbagai sektor. Secara umum, pariwisata dikelompokkan dalam tiga pilar utama, yaitu (1) masyarakat, (2) swasta, (3) pemerintah. Penyelenggaraan sistem pariwisata dapat berjalan dengan sempurna bila komponen-komponen tersebut melebur menjadi satu dan saling mendukung satu dengan lainnya, seperti kewajiban pemerintah adalah bersama-sama merencanakan, pembangunan, pengorganisasian, pemeliharaan, dan pengawasan dengan pemerintah daerah lainnya dalam segala sektor yang mendukung kegiatan pariwisata.

\section{Kajian tentang Pariwisata Halal}

Dalam pandangan Islam, pariwisata diwujudkan dalam hal perjalanan spiritual, tentang pemaknaan dan pencapaian sebuah tuntutan ajaran agama itu sendiri "syahriah". Kenyataan ini telah membuat Saudi Arabia memetik banyak keuntungan baik secara material maupun statusnya sebagai sebuah negara yang memiliki tempat yang dianggap suci oleh kaum muslim yakni Mekkah dan Madinah (Dallen dalam Utama, 2010). Nabi Muhammad SAW memberi petunjuk tentang pandangan Islam dalam berwisata dengan mengatakan "Sesunguhnya wisatanya umatku adalah berjihad di jalan Allah." (HR. Abu Daud, 2486 dalam Syaikh Salim bin 'Ied al-Hilali, 2005), sehingga dalam Islam kegiatan berwisata hendaknya dilakukan dengan niat ibadah. Kegiatan wisata sekaligus beribadah juga dianjurkan dalam rukun Islam yang kelima, yaitu melaksanakan ibadah Haji ke Mekkah, setidaknya sekali seumur hidup bagi mereka yang mampu.

Pariwisata halal dapat didefinisikan sebagai berbagai macam kegiatan wisata yang didukung oleh berbagai fasilitas serta layanan yang disediakan masyarakat, pengusaha dan pemerintah yang memenuhi ketentuan syariah (Rizka, 2016). Pariwisata halal telah diperkenalkan sejak tahun 2000 dari pembahasan pertemuan OKI. Pariwisata halal merupakan suatu permintaan wisata yang didasarkan pada gaya hidup wisatawan muslim selama liburan. Selain itu, pariwisata halal (syariah) merupakan pariwisata yang fleksibel, rasional, sederhana dan seimbang. Pariwisata ini bertujuan agar wisatawan termotivasi untuk mendapatkan kebahagiaan dan berkat dari Allah (Munirah dalam Alim et al, 2014).

Pengembangan pariwisata halal, harus memenuhi delapan faktor sebagai standar pengukuran yang dikembangkan oleh Chookaew et al (2015). Kedelapan faktor tersebut antara lain: 1) Pelayanan kepada wisatawan harus cocok dengan prinsip muslim secara keseluruhan; 2) Pemandu dan staf wisata harus memiliki disiplin dan menghormati prinsip-prinsip Islam; 3) Mengatur semua kegiatan agar tidak bertentangan dengan prinsip Islam; 4) Bangunan harus sesuai dengan prinsip-prinsip Islam; 5) Restoran harus mengikuti standar internasional pelayanan halal; 6) Layanan transportasi harus memiliki keamanan sistem proteksi; 7) Ada tempat-tempat yang disediakan untuk semua wisatawan muslim melakukan kegiatan keagamaan; 8) Bepergian ke tempat-tempat yang tidak bertentangan dengan prinsip Islam.

\section{Daya Saing Sektor Pariwisata Indonesia}

Sektor pariwisata merupakan salah satu sektor jasa yang berkontribusi besar dalam pembangunan dan pertumbuhan ekonomi nasional. Menurut Nizar (2015), sektor pariwisata memiliki keterkaitan (linkages), dengan sejumlah industri lain baik jasa dan non jasa di dalam perekonomian. Pengembangan sektor jasa pariwisata akan mendorong pengembangan sektor lainnya seperti pembangunan infrastruktur serta pertumbuhan industri kreatif seperti kerajinan dan kuliner di daerah tujuan wisata. Keterkaitan tersebut akan berdampak pada penyerapan tenaga kerja, serta peningkatan penerimaan devisa negara dan pajak khususnya pajak tidak langsung. (Nizar, 2015). Selain itu, Yudananto et al (2012), pembangunan kepariwisataan mempunyai peranan penting seperti mendorong pemerataan kesempatan berusaha, mendorong pemerataan pembangunan nasional, berperan dalam mengentaskan kemiskinan yang pada akhirnya akan meningkatkan kesejahteraan rakyat. 
Indonesia merupakan salah satu daerah tujuan wisata dunia yang setiap tahun dikunjungi oleh wisatawan asing maupun domestik, sehingga berdampak pada daya saing sektor pariwisata Indonesia. Menurut data The Travel and Tourism Competitiveness Index (TTCI) 2017, daya saing pariwisata Indonesia di regional Asia Tenggara berada pada peringkat 4 atau peringkat 42 di dunia. Selain itu, The Travel and Tourism Competitiveness Index (TTCI) 2017 menyebutkan bahwa regional Asia Tenggara adalah kawasan pariwisata ramah turis asing (most tourism-friendly destinations). Keunggulan daya saing pariwisata Indonesia terletak pada kekayaan sumber daya alam, keragaman budaya dan keberadaan biro jasa perjalanan wisata, serta harga yang kompetitif.

\section{Data Dan Metodologi}

\section{Desain Penelitian dan Sumber Data}

Desain penelitian yang digunakan adalah penelitian eksploratori dengan jenis penelitian kualitatif. Jenis data yang digunakan adalah data sekunder, yang diperoleh dari dokumen resmi Pemerintah Pusat dan Provinsi Jawa Timur khususnya tentang pariwisata, jurnal penelitian, serta buku dan artikel yang terkait dengan pariwisata khususnya pariwisata halal. Sementara metode pengumpulan data menggunakan studi pustaka.

\section{Metode Analisis Data}

Metode analisis data yang digunakan dalam penelitian ini adalah Analisis SWOT. Langkah-langkah yang digunakan dalam analisis SWOT yaitu:

1. Analisis Faktor-faktor Strategis Internal dan Eksternal (IFAS-EFAS). Penyusunan Tabel IFAS sebagai cara untuk menganalisis lingkungan internal (IFAS) untuk mengetahui berbagai kemungkinan kekuatan dan kelemahan. Sedangkan penyusunan tabel EFAS sebagai cara untuk menganalisis lingkungan eksternal (EFAS) untuk mengetahui berbagai kemungkinan peluang dan ancaman. Dalam penyusunan kedua tabel tersebut dilakukan pembobotan (scoring) dan penilaian rating (Rangkuti, 2015).

2. Analisis Diagram Posisi Perkembangan Pariwisata. Analisis ini memberikan gambaran keadaan perkembangan pariwisata berdasarkan kuadran-kuadran yang dihasilkan garis vektor SW dan garis vektor OT. Setiap kuadran memiliki rumusan strategis sebagai strategi utamanya. Rumusan setiap kuadran yang secara khusus untuk pariwisata dan beberapa pengertian yang melalui proses adaptasi dari penggunaan analisis SWOT untuk perusahaan, sehingga diadaptasi suatu rumusan sebagai berikut (Yoeti dalam Ayungningtias dan Sri, 2017).

3. Analisis Matrik SWOT. Matrik SWOT adalah yang menginteraksikan faktor strategis internal dan eksternal. Matrik ini dapat menggambarkan secara jelas bagaimana peluang dan ancaman (eksternal) yang dihadapi dapat disesuaikan dengan kekuatan dan kelemahan (internal) yang dimiliki (Rangkuti, 2015). Analisis ini akan menghasilkan beberapa alternatif strategi yaitu:

a. Strategi SO: Strategi ini dibuat dengan memanfaatkan seluruh kekuatan untuk merebut dan memanfaatkan peluang sebesar-besarnya. Strategi SO menggunakan kekuatan internal untuk memanfaatkan peluang eksternal.

b. Strategi ST: Strategi ini menggunakan kekuatan untuk mengatasi ancaman. Strategi ST menggunakan kekuatan internal untuk menghindari atau mengurangi dampak ancaman eksternal.

c. Strategi WO: Strategi ini diterapkan berdasarkan pemanfaatan peluang yang ada dengan cara meminimalkan kelemahan yang ada. Strategi WO bertujuan untuk memperbaiki kelemahan internal dengan memanfaatkan peluang eksternal.

d. Strategi SW: Strategi ini didasarkan pada kegiatan yang bersifat defensif dan berusaha meminimalkan kelemahan serta menghindari ancaman. Strategi WT bertujuan untuk mengurangi kelemahan internal dengan menghindari ancaman eksternal.

Gambar 1. Model Posisi Perkembangan Pariwisata 


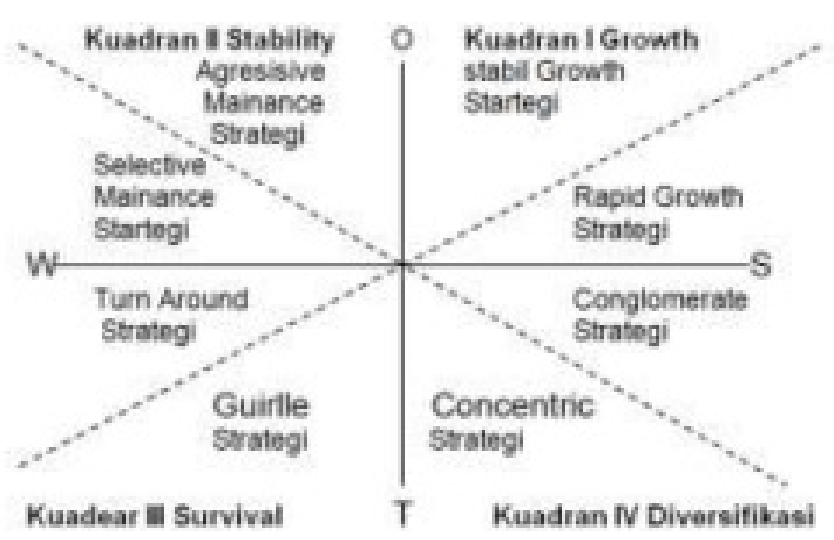

Sumber : Yoeti dalam Ayungningtias dan Sri (2017)

\section{Hasil Dan Analisis}

\section{Analisis Faktor Eksternal \& Internal dalam Pengembangan Pariwisata Halal Jatim}

\section{Analisis Eksternal}

\section{a. Peluang}

1. Dukungan kebijakan pemerintah pusat dan daerah

Kementerian Pariwisata telah menetapkan 13 provinsi sebagai destinasi wisata halal unggulan. 13 provinsi tersebut antara lain Nusa Tenggara Barat (NTB), Nangroe Aceh Darussalam, Sumatera Barat, Riau, Lampung, Banten, DKI Jakarta, Jawa Barat, Jawa Tengah, Yogyakarta, Jawa Timur, Sulawesi Selatan, dan Bali. Penetapan daerah tersebut merupakan bagian dari target pemerintah untuk menjadikan Indonesia sebagai kiblat pariwisata halal dunia (Andriani, 2015). Provinsi Jawa Timur mendukung penuh program tersebut dengan mengembangkan pariwisata halal di beberapa kabupaten kota.

Di Jawa Timur, beberapa daerah seperti Kota Malang dan Kabupaten Pasuruan mulai mengembangkan pariwisata halal. Awal tahun 2017, Dinas Kebudayaan dan Pariwisata (Disbudpar) Kota Malang secara intensifmelakukan sosialisasi kepada pelaku industri wisata di Kota Malang tentang pariwisata halal. Pengembangan pariwsata halal di Kota Malang yaitu sajian menu makanan dan layanan hotel yang mencerminkan kehalalan. Khusus untuk layanan hotel, Disbudpar Kota Malang menghimbau agar hotel-hotel wajib memiliki mushala serta peralatan shalat di setiap kamar (Hartik, 2016). Sementara itu, fokus pengembangan pariwisata halal di Kabupaten Pasuruan akan dimulai pada tahun 2018. Keseriusan Pemerintah Kabupaten Pasuruan didasarkan pada keberadaan destinasi wisata yang terbilang lengkap yaitu wisata alam pegunungan, air terjun, pemandian rakyat, danau, wisata keluarga, wisata religi dan sejarah dan kuliner. (Andi, 2017).

Badan Pengembangan Wilayah Surabaya-Madura (BPWS) juga berencana untuk mengembangkan pariwisata halal di Pulau Madura. Menurut BPWS, fokus pengembangan pariwisata halal di Pulau Madura adalah wisata syariah. Hal ini disesuaikan dengan kondisi sosial masyarakat Pulau Madura yang religius, dimana $90 \%$ penduduk di Pulau Madura memeluk agama islam. Potensi pengembangan wisata syariah di Pulau Madura juga terlihat dari akulturasi budaya lokal yang telah dipengaruhi oleh ajaran-ajaran agama Islam dan keberadaan objek wisata religi mulai bangunan masjid dan istana kesultanan di Pulau Madura. (Mardiana, 2017).

2. Keberadaan lembaga sertifikasi halal dan atau syariah untuk sarana penunjang pariwisata halal

Sertifikasi usaha pariwisata halal telah diatur dalam Peraturan Menteri Pariwisata Republik Indonesia Nomor 1 Tahun 2016 Tentang Penyelenggaraan Sertifikasi Usaha Pariwisata. Dalam peraturan tersebut, Sertifikasi Usaha Pariwisata Halal dilakukan oleh Dewan Syariah Nasional - Majelis Ulama Indonesia (DSN-MUI). DSN-MUI menerbitkan sertifikasi kesesuaian syariah pada badan usaha salah satunya adalah sertifikasi hotel. Setiap hotel yang akan men- 
erapkan layanan berbasis syariah harus mendapatkan sertifikasi kesesuaian syariah dari DSNMUI.

Selain MUI, lembaga non pemerintah yang dapat mendukung pengembangan pariwisata halal juga terdapat di Jawa Timur yaitu Yayasan Halalan Thoyyiban Indonesia yang berada di Kota Batu. Yayasan ini bertujuan untuk mewujudkan konsumen cerdas, produsen bertanggungjawab berbasis halal dan thoyyib. Aktivitas dalam Yayasan Halalan Thoyyiban Indonesia mencakup penelitian terintegrasi berbasis halal dan thoyyib, pengabdian masyarakat, rekomendasi kepada stakeholders. Selain itu, pengembangan pariwisata halal di Jawa Timur juga didukung melalui keberadaan pusat studi halal di pendidikan tinggi. Contoh Pusat Studi Halalan Thoyyiban atau Halal Thoyib Science Center Universitas Brawijaya, Pusat Studi Kajian UIN Maulana Malik Ibrahim Malang, dan Pusat Kajian Halal Institut Teknologi Sepuluh November Surabaya.

\section{Reputasi pariwisata halal Indonesia di tingkat internasional}

Pariwisata halal Indonesia telah mendapatkan pengakuan dalam ajang World Halal Tourism Award selama dua tahun terakhir yaitu 2015 dan 2016. Penghargaan tersebut merupakan wujud pengakuan dunia internasional terhadap potensi dan pesona pariwisata halal Indonesia. Indonesia mendapatkan tiga penghargaan dalam World Halal Tourism Award 2015 yaitu World's Best Halal Tourism Destination (Lombok), World's Best Halal Honeymoon Destination (Lombok), dan World's Best Family Friendly Hotel (Sofyan Hotel). Sedangkan dalam ajang World Halal Tourism Award 2016, Indonesia mendapatkan 12 kategori penghargaan dari 16 kategori.

Reputasi tersebut telah menarik wisatawan muslim mancanegara untuk berkunjung ke Indonesia. Menurut data Kementerian Pariwisata tahun 2014 dalam Suherlan (2015), kunjungan wisatawan muslim ke Indonesia mencapai 1.270.437 orang per tahun yang berasal dari Arab Saudi, Bahrain, Malaysia, Brunei, Singapura dan Prancis. Selain itu, beberapa maskapai penerbangan negara Timur Tengah dan negara Islam telah membuka rute penerbangan langsung ke Indonesia melalui Jakarta, Denpasar, dan Surabaya. Maskapai tersebut antara lain Emirates, EgyptAir, Qatar, Etihad Airways, Turkish Airlines, Saudi Arabian Airlines, Malaysia Airlines, AirAsia, dan Royal Brunei Airlines. Keberadaan maskapai tersebut turut serta dalam peningkatkan kunjungan wisatawan muslim ke Indonesia.

\section{b. Ancaman}

1. Stabilitas ekonomi daerah, nasional, regional, internasional dan global

Stabilitas ekonomi merupakan salah satu faktor yang mendorong tingginya tingkat konsumsi masyarakat. Ketidakstabilan ekonomi baik ditingkat daerah, nasional, regional, internasional dan global akan berdampak pada kurangnya daya beli masyarakat khususnya keperluan untuk berlibur. Masyarakat akan enggan mengalokasikan dananya untuk berwisata saat kondisi ekonomi sedang terpuruk. Hal ini karena masyarakat akan mengalokasikan dananya untuk kebutuhan pokok, sedangkan berwisata adalah kebutuhan sekunder.

\section{Stabilitas keamanan dalam dan luar negeri}

Salah satu faktor penenntu kunjungan masyarakat untuk berwisata adalah masalah kemanan daerah tujuan wisata. Negara-negara yang dirasa tidak aman akan mempengaruhi keputusan berkunjung dan pemerintah akan mengeluarkan travel warning bagi warganya agar tidak berkunjung ke daerah tersebut. Sebagai contoh, penyerangan teroris yang dilakukan di Indonesia membuat beberapa negara mengeluarkan imbauan perjalanan (travel advice). Pasca ledakan bom di Terminal Bus Kampung Melayu di Jakarta membuat Kedutaan Besar Amerika Serikat di Indonesia secara resmi meminta seluruh warganya yang akan berkunjung atau tinggal di Indonesia untuk meninjau kembali rencana bepergian tersebut. Selain itu, Pemerintah Australia melalui Kementerian Luar Negerinya memberikan status "high degree of caution" atau kewaspadaan tingkat tinggi di Indonesia. Hal serupa juga dilakukan oleh pemerintah Inggris pasca Pasca ledakan bom di Terminal Bus Kampung Melayu (Zuraya, 2017).

Pada tahun 2015, kedutaan besar AS pernah mengeluarkan peringatan travel warn- 
ing terkait adanya potensi ancaman keamanan hotel, bank dan aset yang berhubungan dengan AS di Jawa Timur (DetikNews, 2017). Hal terbaru adalah potensi bencana alam Gunung Agung yang menyebabkan lima negara Singapura, Inggris, Australia, Amerika Serikat, dan New Zealand mengeluarkan imbauan resmi (travel advices) ke Indonesia (Prodjo, 2017). Isuisu stabilitas kemanan seperti serangan teroris, bencana alam, dan kerusahan menjadi pertimbangan utama bagi wisatawan untuk bepergian karena menyangkut keselamatan diri selama berkunjung ke suatu daerah tujuan wisata. Wisatawan cenderung menghindari daerah tujuan wisata yang dirasa tidak dapat memberikan jaminan kesematan seperti daerah yang sering mengalami konflik, diserang teroris ataupun bencana alam.

\section{Persaingan antar daerah dan negara dalam pengembangan pariwisata halal}

Persaingan antar daerah dan negara dalam pengembangan pariwisata halal tidak dapat terelakkan. Ditingkat dunia, menurut data Global Muslim Travel Index (GMTI) tahun 2016, Indonesia berada pada peringkat 4 dengan nilai 70,6 perihal top 10 destinasi pariwisata halal populer negara-negara yang tergabung The Organization of Islamic Cooperation. Indonesia kalah dengan Malaysia yang menempati peringkat 1 dunia. Sedangkan menurut laporan State of the Global Islamic Economy tahun 2015-2016, Indonesia tidak masuk dalam peringkat Top 5 Countries For The Halal Travel Indicator. Lima negara favorit tujuan wisata halal menurut laporan State of the Global Islamic Economy adalah Malaysia, Uni Emirat Arab, Singapura, Thailand dan Yordania.

Pada tingkat nasional, pariwisata halal Jawa Timur harus bersaing dengan 12 provinsi yang sudah ditetapkan oleh Kementerian Pariwisata sebagai destinasi wisata halal unggulan. Pada tahun 2016, Kementerian Pariwisata menyelenggarakan Kompetisi Pariwisata Halal Tingkat Nasional (KPHN) yang bertujuan untuk mendorong pemerintah daerah dalam pengembangan pariwisata halal Indonesia. Terdapat 15 kategori yang dilombakan, namun tidak ada satupun yang dimenangkan oleh Provinsi Jawa Timur. Saingan terberat Jawa Timur dalam pengembangan pariwisata halal adalah Nusa Tenggara Barat (NTB), Nangroe Aceh Darussalam, Sumatera Barat, DKI Jakarta, Jawa Barat, dan Bali. Pada kompetisi tersebut, Provinsi Nangroe Aceh Darussalam, Sumatera Barat dan NTB mendapat penghargaan terbanyak.

\section{Analisis Internal}

\section{a. Kekuatan}

\section{Keberagaman daerah tujuan wisata di Provinsi Jawa Timur}

Popularitas daerah tujuan wisata Provinsi Jawa Timur tersebar di 29 kabupaten dan 9 daerah kota. Masing-masing daerah tujuan wisata Jawa Timur menawarkan atraksi wisata yang unik, menarik serta sarat akan budaya khas Jawa Timuran. Objek wisata Provinsi Jawa Timur terbilang lengkap mulai dari wisata alam, wisata budaya, wisata belanja, wisata olahraga serta wisata buatan. Beberapa objek wisata tersebut telah terkenal baik di tingkat nasional maupun internasional. Sebagai contoh, Kota Batu yang populer di kalangan wisatawan domestik memiliki banyak objek wisata, mulai dari wisata buatan (Museum Angkut, Batu Night Spectacular, Jatim Park 1 dan 2, Batu Secret Zoo, Museum Satwa dan lain-lain), wisata olahraga (arum jeram, gokart), wisata agropolitan (Kebun Apel Agrokusuma, Desa Wisata Bunga Sidomulyo) hingga wisata alam. Sedangkan objek wisata yang terkenal hingga tingkat internasional adalah Wisata Gunung Bromo, Wisata Blue Fire Kawah Gunung ljen, dan lainlain. Selain itu, daerah-daerah di Provinsi Jawa Timur juga mengembangkan wisata budaya melalui penyelenggaraan festival sebagai bagian dari agenda tahunan untuk mendatangkan wisatawan, diantaranya Jember Fashion Carnaval dan Festival Gandrung Sewu di Kabupaten Banyuwangi.

Objek wisata lainnya yang sedang berkembang di Provinsi Jawa Timur adalah objek wisata kampung kota di Kota Malang. Kampung wisata di Kota Malang merupakan program pemerintah Kota Malang melalui program Kampung Tematik. Beberapa kampung wisata kota di Kota Malang antara lain Kampung Warna Warni Jodipan, Kampung Tridi Kesatrian, Kampung Keramik Dinoyo, dan Kampung Topeng Malangan.

Kekuatan dalam pengembangan pariwisata halal di Jawa Timur juga ditunjang oleh 
keberadaan wisata religi Islam. Wisata religi Islam yang berkembang di Jawa Timur tidak terlepas dari sejarah perkembangan penyebaran agama di Islam di Indonesia. Wisata religi di Jawa Timur merupakan bentuk dari napak tilas jejak penyebaran agama Islam yang dilakukan oleh wali dan ulama di Indonesia khususnya di Provinsi Jawa Timur. Wisata napak tilas jejak wali di Jawa Timur dikenal dengan nama "Wali Limo". Lima dari sembilan wali (Wali Songo) yang terkenal sebagai tokoh penyebar agama islam di Nusantara dimakamkan di Jawa Timur. Wisata religi napak tilas Wali Limo yaitu Sunan Ampel (Raden Rahmat) Surabaya, Sunan Gresik (Maulana Malik Ibrahim) Gresik, Sunan Giri (Raden Paku) Gresik, Sunan Drajat (Raden Qasim) Lamongan, dan Sunan Bonang (Raden Maulana Makdum Ibrahim) Tuban. Wisata religi napak tilas Wali Limo telah mendatangkan banyak wisatawan khususnya wisatawan domestik dari seluruh Indonesia. Selain wisata religi napak tilas Wali Limo, Wisata yang menawarkan unsur kebudayaan islam adalah objek peninggalan dari zaman kerajaan Islam di Jawa Timur. Contohnya adalah Keraton Sumenep dan Masjid Jami di Pulau Madura, Masjid Cheng Ho di Pasuruan dan Masjid Tiban di Kabupaten Malang.

\section{Prasarana penunjang mobilitas wisatawan di Jawa Timur}

Prasarana penunjang mobilitas wisatawan di Jawa Timur terbilang lengkap mulai dari moda transaportasi darat, laut dan udara. Seluruh kabupaten dan kota di Jawa Timur telah terhubung melalui infrastruktur transportasi darat baik melalui jalan raya maupun jalur jalur kereta api. Provinsi Jawa Timur dilalui oleh Jalan Nasional Rute 1 atau Jalur Pantura (Jalur Pantai Utara). Jalan Nasional Rute 1 Provinsi Jawa Timur menghubungkan kabupaten dan kota di sepanjang pesisir pantai utara Jawa yaitu Tuban, Lamongan, Gresik, Surabaya, Sidoarjo, Kabupaten Pasuruan, Kota Pasuruan, Probolinggo, Situbondo dan Banyuwangi.

Selain Jalan Nasional Rute 1, kabupaten dan kota di Jawa Timur juga terhubung oleh Jalan Tol Trans Jawa yang merupakan proyek nasional untuk mengubungkan Jakarta dan Surabaya. Beberapa daerah di Jawa Timur yang dilalui oleh Jalan Tol Trans Jawa antara lain Jalur Utara (Jalan Tol Surabaya-Gresik), Jalur Tengah (Jalan Tol Ngawi-Kertosono, Jalan Tol Mojokerto-Kertosono, Jalan Tol Surabaya-Mojokerto, Jalan Tol Gempol-Pasuruan, Jalan Tol Pasuruan-Probolinggo, Jalan Tol Probolinggo-Banyuwangi, Jalan Tol Waru-Juanda, Jalan Tol Surabaya Porong, Jalan Tol Porong-Gempol, Jalan Tol Jembatan Nasional Suramadu), dan jalur Selatan (Jalan Tol Gempol-Pandaan dan Jalan Tol Pandaan-Malang).

Selain melalui jalan raya atau tol, pilihan transportasi darat yang bisa digunakan oleh wisatawan adalah kereta api. Jalur kereta api di Jawa Timur terdiri dari tiga jalur yaitu jalur utara, jalur tengah dan jalur selatan. Jalur utara menghubungkan kabupaten kota di pesisir pantai utara jawa seperti Sidoarjo, Gresik, Lampongan dan Babat. Jalur tengah mengubungkan Jombang, Kediri, Madiun, Nganjuk, dan Ngawi. Jalur selatan menghubungan Malang, Banyuwangi, Jember, Probolinggo, Blitar, dan Pasuran (Pandaan dan Bangil). Masing-masing jalur tersebut juga terhubung dengan kota-kota besar di Pulau Jawa seperti Malang-Jakarta, Malang-Bandung, Malang-Yogkarta Surabaya-Jakarta, Surabaya-Bandung, Surabaya Semarang, Kediri-Jakarta, Kediri-Bandung.

Moda transportasi lainnya yang bisa digunakan oleh wisatawan adalah udara dan laut. Pilihan moda transportasi udara di Jawa Timur adalah bandara. Provinsi Jawa Timur memiliki lima bandara yang melayani penerbangan komersil yaitu Bandar Udara Abdul Rachman Saleh, Bandar Udara Notohadinegoro, Bandar Udara Blimbingsari, Bandar Udara Internasional Juanda, dan Bandar Udara Trunojoyo. Bandar Udara Internasional Juanda merupakan satu-satunya bandar udara internasional di Jawa Timur yang melayani rute penerbangan luar negeri ke Surabaya. Khusus untuk penerbangan internasional ke negara-negara Islam yaitu Surabaya Kualalumpur-Penang-Johor Bahru (Malaysia), Surabaya-Bandar Sri Begawan (Brunai Darussalam) dan Surabaya-Jeddah-Madinah-Riyadh (Arab Saudi). Sedangkan ke empat lainnya hanya melayani penerbangan domestik seperti Malang-Jakarta, Malang-Denpasar, Jember-Surabaya-Jakarta, Banyuwangi-Jakarta.

Pilihan moda transportasi laut yang dapat digunakan oleh wisatawan ketika berkunjung ke Jawa Timur adalah Pelabuhan Tanjung Perak di Kota Surabaya dan Pelabuhan Ketapang di Kabupaten Banyuwangi. Fasilitas Pelabuhan Tanjung Perak yang dapat melayani wisatawan terdapat di Terminal Gapura Surya Nusantara yang melayani penyeberangan pen- 
umpang Tanjung Perak ke kota-kota pelabuhan lain di Indonesia serta Dermaga Kapal Pesiar yang melayani kapal pesiar baik dari dalam negeri maupun luar negeri. Sedangkan Pelabuhan Ketapang dapat menjadi alternatif bagi wisatawan dari Bali yang hendak berkunjung ke Jawa Timur melalui Kabupaten Banyuwangi.

\section{Tingkat kunjungan wisatawan domestik dan mancanegara di Provinsi Jawa Timur}

Berdasarkan data Survei Profil Wisatawan Nusantara selama tahun 2012- 2016, jumlah perjalanan wisatawan domestik yang bertujuan ke Provinsi Jawa Timur merupakan yang tertinggi diantara 34 provinsi di Indonesia. Menurut data BPS, setiap tahun jumlah wisatawan domestik yang berkunjung ke Jawa Timur mencapai puluhan juta orang. Rata-rata Lama Menginap Tamu (RLMT) wisatawan domestik di seluruh hotel yang ada di Provinsi Jawa Timur yaitu 1 hingga 2 hari.

Grafik 1. Jumlah Wisatawan Mancanegara yang Datang ke Jawa Timur Melalui Pintu Masuk Juanda Tahun 2015-2017

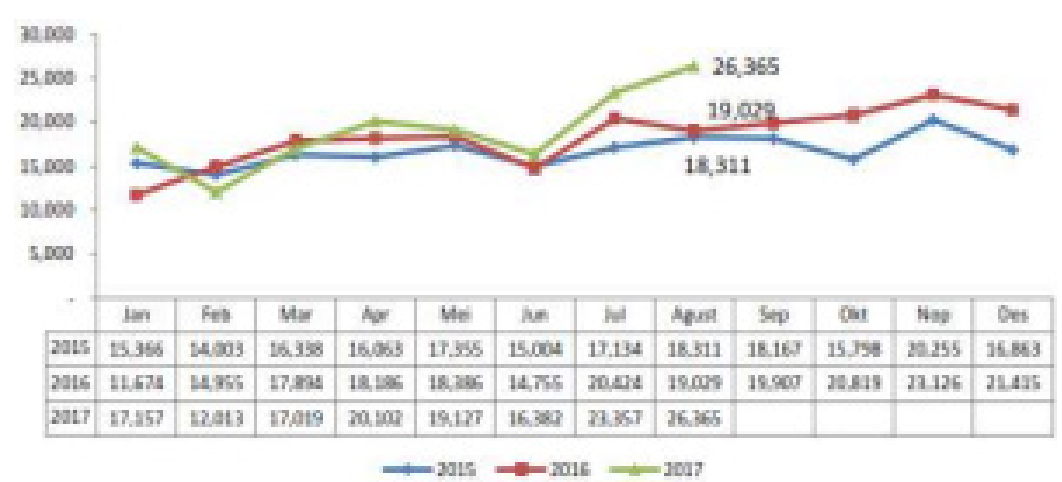

Sumber : BPS Provinsi Jawa Timur (2017)

Perjalanan wisatawan mancanegara ke Jawa Timur berdasarkan pintu masuk Juanda berada pada peringkat ke- 5 setelah Bali, Jakarta, Batam, serta Medan dan selama tahun 2015 hingga Agustus 2017 menunjukkan peningkatan. Menurut data BPS Jawa Timur, Jumlah kunjungan wisatawan mancanegara dari Bulan Januari hingga Agustus 2017 mencapai 151.522 kunjungan atau naik 11,99\% dibanding jumlah wisman periode yang sama tahun 2016 yang mencapai 135.303 kunjungan. Negara asal wisatawan mancanegara terbanyak yang berkunjung ke Jawa Timur adalah Malaysia, kemudian Singapura dan Tiongkok. Rata-rata Lama Menginap Tamu (RLMT) wisatawan mancanegara pada hotel berbintang 2 sampai 3 hari.

\section{b. Kelemahan}

1. Promosi dan branding pariwisata halal Jawa Timur

Pengembangan pariwisata halal Jawa Timur masih dihadapkan pada permasalahan promosi. Menurut Arby (2012) kurangnya promosi dari pelaku industri wisata menyebabkan pariwisata halal Indonesia tersendat dan tertinggal dibandingkan dengan negara muslim lainnya. Kendala promosi tersebut menyebabkan wisatawan minim informasi mengenai keberadaan pariwisata halal di daerah-daerah Jawa Timur. Hal ini karena fokus program branding destinasi pariwisata yang dilakukan pemerintah di kabupaten dan kota Jawa Timur masih sebatas promosi pariwisata konvensional tanpa menyebutkan pariwisata halal secara spesifik. Akibatnya branding pariwisata halal Jawa Timur kalah jika dibandingkan dengan daerah-daerah di Indonesia seperti Provinsi Nusa Tenggara Barat, Sumatera Barat dan Nanggroe Aceh Darussalam (NAD).

Kelemahan lainnya yang menghambat pengembangan pariwisata halal Jawa Timur adalah peran industri jasa pariwisata lokal. Penelitian Andriani (2015) juga menjelaskan bahawa permasalahan lainnya adalah belum banyak biro perjalanan yang mengemas perjalanan inbound dengan paket halal travel di Indonesia, tetapi lebih banyak pengemasan perjala- 
nan outbound seperti umrah dan haji. Mayoritas usaha tour and travel di Jawa Timur hanya menyediakan paket wisata tanpa mempertimbangkan aspek kehalalan selama berwisata, seperti pemilihan akomodasi hotel yang tidak bersertifikat syariah bagi wisatawan muslim.

\section{Sarana pendukung pariwisata halal}

Saranan pendukung seperti hotel syariah merupakan hal terpenting dalam pengembangan pariwisata halal Jawa Timur. Secara nasional jumlah hotel syariah yang sudah bersertifikat dari MUI adalah 37 hotel dari dari 9.812 hotel yang ada di Indonesia. Minimnya jumlah hotel bersertifikat syariah khususnya di Jawa Timur disebabkan oleh tingginya biaya investasi untuk hotel syariah karena adanya penambahan beberapa fasilitas dari berbagai aspek yang sesuai dengan regulasi Kementerian Pariwisata dan MUI (Kelana, 2015). Selain hotel, sarana pendukung pariwisata halal seperti objek wisata buatan khusus (bertemakan Islam) belum tersedia di Jawa Timur. Objek-objek wisata yang sudah ada dan akan dibangun umumnya taman hiburan dan bermain. Sarana lain yaitu keberadaan pusat informasi resmi yang bisa diakses oleh wisatawan muslim. Sebagai contoh official website milik pemerintah belum memiliki kanan khusus untuk pariwisata halal Jawa Timur.

\section{Sumber daya manusia yang ahli dalam bidang pariwisata halal}

Kelemahan lain dalam pengembangan pariwisata halal di Jawa Timur adalah ketersediaan sumber daya manusia (SDM) yang ahli di bidang pariwisata halal. Sejauh ini, perguruan tinggi baik negeri maupun swasta di Jawa Timur yang menawarkan jurusan atau program studi pariwisata belum memiliki konsentrasi pariwisata halal. Sebagai contoh kurikulum program studi (S1) bisnis pariwisata di Universitas Brawijaya tidak memiliki mata kuliah khusus tentang pariwisata halal. Hal serupa juga ditemui di kurikulum program studi vokasi Pariwisata di Fakultas Vokasi Universitas Airlangga.

Selain tingkat pendidikan tinggi, sekolah menengah kejuruan bidang pariwisata yang ada di Jawa Timur belum memiliki mata pelajaran khusus tentang pariwisata halal. Hal ini menjadi penyebab keterbatasan SDM baik SDM praktikal maupun SDM akademisi dalam bidang pariwisata halal. Keberadaan SDM yang ahli dalam bidang pariwisata dapat membantu pengembangan pariwisata halal Jawa Timur seperti hasil kajian penelitian dari akademisi yang menjadi masukan dalam perancangan kebijakan di dinas pariwisata tentang pariwisata halal. SDM praktikal juga diperlukan untuk mendukung pengembangan industri pariwisata halal di Jawa Timur seperti manajemen perjalanan wisata halal, hotel syariah, industri kuliner halal dan lain-lain.

\section{Perumusan Strategi Pengembangan Pariwisata Halal Jawa Timur External Factors Analysis Summary (EFAS)}

Berdasarkan tabel 2, matriks EFAS potensi pengembangan pariwisata halal Provinsi Jawa Timur memiliki total nilai skor untuk faktor peluang yaitu 1,88. Ancaman dari potensi pengembangan pariwisata halal Provinsi Jawa Timur memiliki total nilai skoring 1,04.

Tabel 2. EFAS Potensi Pengembangan Pariwisata Halal Provinsi Jawa Timur

\begin{tabular}{|c|c|c|c|c|}
\hline $\begin{array}{c}\text { Faktor-Faktor } \\
\text { Eksternal Uta- } \\
\text { ma }\end{array}$ & $\begin{array}{c}\text { Bob- } \\
\text { ot }\end{array}$ & $\begin{array}{l}\text { Per- } \\
\text { ingkat }\end{array}$ & Skor & Keterangan \\
\hline Peluang & & & & \\
\hline
\end{tabular}




\begin{tabular}{|c|c|c|c|c|}
\hline $\begin{array}{c}\text { Faktor-Faktor } \\
\text { Eksternal Uta- } \\
\text { ma }\end{array}$ & $\begin{array}{c}\text { Bob- } \\
\text { ot }\end{array}$ & $\begin{array}{c}\text { Per- } \\
\text { ingkat }\end{array}$ & Skor & Keterangan \\
\hline $\begin{array}{l}\text { Dukungan } \\
\text { kebijakan } \\
\text { pemerintah } \\
\text { pusat } \\
\text { dan daerah }\end{array}$ & 0,18 & 3 & 0,54 & $\begin{array}{l}\text { Dukungan kebijakan tersebut pen- } \\
\text { etapan Provinsi Jawa Timur sebagai } \\
\text { salah satu daerah prioritas pengem- } \\
\text { bangan pariwisata halal nasional oleh } \\
\text { Kementerian Pariwisata dan UU Oto- } \\
\text { nomi Daerah (UU No } 32 \text { Tahun } 2004 \\
\text { Tentang Pemerintah Daerah dan UU } \\
\text { No } 23 \text { Tahun } 2014 \text { Tentang Pemerin- } \\
\text { tah Daerah dan Pembagian Wilayah) }\end{array}$ \\
\hline $\begin{array}{l}\text { Keberadaan } \\
\text { lembaga } \\
\text { sertifikasi } \\
\text { halal dan } \\
\text { atau syariah } \\
\text { untuk sarana } \\
\text { penunjang } \\
\text { pariwisata } \\
\text { halal }\end{array}$ & 0,18 & 3 & 0,54 & $\begin{array}{l}\text { Keberadaan lembaga sertifikasi halal } \\
\text { oleh Kementerian Agama dan Maje- } \\
\text { lis Ulama Indonesia. Sertifikasi halal } \\
\text { mencakup makanan dan minuman, } \\
\text { sedangkan sertifikasi syariah seperti } \\
\text { hotel. }\end{array}$ \\
\hline $\begin{array}{l}\text { Reputasi } \\
\text { pariwisata } \\
\text { halal Indo- } \\
\text { nesia } \\
\text { ditingkat } \\
\text { internasional }\end{array}$ & 0,20 & 4 & 0,80 & $\begin{array}{l}\text { Selama dua tahun terakhir pari- } \\
\text { wisata halal Indonesia telah banyak } \\
\text { mendapakan penghargaan internasi- } \\
\text { onal melalui ajang World Halal Tour- } \\
\text { ism Award. Penghargaan tersebut } \\
\text { adalah bentuk pengakuan dunia ter- } \\
\text { hadap kualitas pariwisata halal Indo- } \\
\text { nesia. }\end{array}$ \\
\hline
\end{tabular}

SUB TOTAL PEL- $0,56 \quad 1,88$
UANG

\begin{tabular}{|c|c|c|c|c|}
\hline Ancaman & & & & \\
\hline $\begin{array}{l}\text { Stabilitas } \\
\text { ekonomi } \\
\text { daerah, } \\
\text { nasional, } \\
\text { regional, } \\
\text { internasional } \\
\text { dan } \\
\text { global }\end{array}$ & 0,15 & 2 & 0,30 & $\begin{array}{l}\text { Stabilitas ekonomi yang dimaksud } \\
\text { adalah stabilitas ekonomi daerah, } \\
\text { nasional, regional, internasional dan } \\
\text { global. Hal ini terlihat dari daya beli } \\
\text { masyarakat khususnya wisatawan } \\
\text { yang terus meningkat khususnya un- } \\
\text { tuk pengeluaran kebutuhan dan ke- } \\
\text { ingan berwisata }\end{array}$ \\
\hline
\end{tabular}




\begin{tabular}{|c|c|c|c|c|}
\hline $\begin{array}{l}\text { Faktor-Faktor } \\
\text { Eksternal Uta- } \\
\text { ma }\end{array}$ & $\begin{array}{c}\text { Bob- } \\
\text { ot }\end{array}$ & $\begin{array}{l}\text { Per- } \\
\text { ingkat }\end{array}$ & Skor & Keterangan \\
\hline $\begin{array}{l}\text { Stabilitas } \\
\text { keamanan } \\
\text { dalam dan } \\
\text { luar } \\
\text { negeri }\end{array}$ & 0,16 & 3 & 0,48 & $\begin{array}{l}\text { Stabilitas keamanan yang dimaksud } \\
\text { adalah stabilitas kemanan daerah } \\
\text { khususnya daerah tujuan wisata di } \\
\text { Provinsi Jawa Timur. Suasana yang } \\
\text { aman dan kondusif merupakan salah } \\
\text { satu faktor utama wisatawan memu- } \\
\text { tuskan untuk berkunjung ke daerah } \\
\text { tujuan wisata. }\end{array}$ \\
\hline $\begin{array}{l}\text { Persaingan } \\
\text { antar } \\
\text { daerah } \\
\text { dan negara } \\
\text { dalam } \\
\text { pengemban- } \\
\text { gan } \\
\text { pariwisata } \\
\text { halal }\end{array}$ & 0,13 & 2 & 0,26 & $\begin{array}{l}\text { Persaingan pariwisata halal Jawa } \\
\text { Timur tidak hanya dilingkup nasional } \\
\text { namun juga lingkup global. Karena } \\
\text { pengembangan pariwisata halal telah } \\
\text { menjadi trend di seluruh dunia, baik } \\
\text { negara muslim maupun nonmuslim }\end{array}$ \\
\hline $\begin{array}{r}\text { SUB TOTAL AN- } \\
\text { CAMAN }\end{array}$ & 0,44 & & 1,04 & \\
\hline
\end{tabular}

TOTAL $\quad 1,00 \quad 2,92$

\section{Internal Factors Analysis Summary (IFAS)}

Berdasarkan tabel 3, matriks IFAS potensi pengembangan pariwisata halal Provinsi Jawa Timur memiliki total nilai skor untuk faktor kekuatan yaitu 2,37. Kelemahan dari potensi pengembangan pariwisata halal Provinsi Jawa Timur memiliki total nilai skoring 1,13.

Tabel 3. IFAS Potensi Pengembangan Pariwisata Halal Provinsi Jawa Timur

\begin{tabular}{llccc}
\hline $\begin{array}{c}\text { Faktor-Faktor } \\
\text { Eksternal Utama }\end{array}$ & Bobot & $\begin{array}{c}\text { Per- } \\
\text { ingkat }\end{array}$ & Skor & \multicolumn{1}{c}{ Keterangan } \\
\hline Kekuatan & & & & \\
\hline $\begin{array}{l}\text { Keberagaman } \\
\text { daerah tujuan }\end{array}$ & 0,24 & 4 & 0,96 & $\begin{array}{l}\text { Provinsi Jawa Timur terdirid dari 29 } \\
\text { daerah kabupaten dan 9 daerah kota. } \\
\text { wisata di }\end{array}$ \\
$\begin{array}{l}\text { Provinsi Jawa } \\
\text { Timur }\end{array}$ & & & $\begin{array}{l}\text { Masing-masing kabupaten dan kota } \\
\text { Provinsi Jawa Timur menawarkan at- } \\
\text { raksi wisata yang beragam dan unik } \\
\text { sehingga menjadi daya tarik sendiri } \\
\text { dan dapat disesuaikan berdasarkan } \\
\text { kebutuhan dan keingnan wisatawan } \\
\text { domestik maupun mancanegara }\end{array}$ \\
\hline
\end{tabular}




\begin{tabular}{|c|c|c|c|c|}
\hline $\begin{array}{l}\text { Prasarana } \\
\text { penunjang } \\
\text { mobilitas } \\
\text { wisatawan } \\
\text { domestik dan } \\
\text { mancanegara } \\
\text { di Jawa Timur }\end{array}$ & 0,19 & 3 & 0,57 & $\begin{array}{l}\text { Prasarana penunjang mobilitas wisa- } \\
\text { tawan di Jawa Timur terbilang leng- } \\
\text { kap mulai dari pilihan moda tran- } \\
\text { saportasi (udara, darat dan laut). } \\
\text { Hampir seluruh wilayah kabupaten } \\
\text { kota Jawa Timur terhubung oleh jalur } \\
\text { kereta api dan tol jawa. Keberadaan } \\
\text { bandara yang melayani penerbangan } \\
\text { internasional (Surabaya) dan domes- } \\
\text { tik (Malang) serta perintis (Madura, } \\
\text { Jember dan Banyuwagi) }\end{array}$ \\
\hline $\begin{array}{l}\text { Tingkat kunjun- } \\
\text { gan } \\
\text { wisatawan do- } \\
\text { mestik }\end{array}$ & 0,21 & 4 & 0,84 & $\begin{array}{l}\text { Setiap tahun kunjungan wisatawan } \\
\text { domestik dan mancanegara di berb- } \\
\text { agai daerah tujuan wisata }\end{array}$ \\
\hline $\begin{array}{l}\text { dan man- } \\
\text { canegara di } \\
\text { Provinsi Jawa } \\
\text { Timur }\end{array}$ & & & & $\begin{array}{l}\text { Provinsi Jawa Timur terus mengalami } \\
\text { peningkatan. }\end{array}$ \\
\hline $\begin{array}{l}\text { SUB TOTAL PEL- } \\
\text { UANG }\end{array}$ & 0,64 & & 2,37 & \\
\hline \multicolumn{5}{|l|}{ Kelemahan } \\
\hline $\begin{array}{l}\text { Promosi dan } \\
\text { branding pari- } \\
\text { wisata halal } \\
\text { Jawa Timur }\end{array}$ & 0,15 & 3 & 0,45 & $\begin{array}{l}\text { Promosi pariwisata halal Indonesia } \\
\text { khususnya Jawa Timur tidak semas- } \\
\text { if jika dibandingkan dengan promo- } \\
\text { si pariwisata konvensional. Hal ini } \\
\text { menyebabkan branding pariwisata } \\
\text { halal Jawa Timur belum terbangun. } \\
\text { Sehingga wisatawan baik domestik } \\
\text { maupun mancanegara kurang akses } \\
\text { informasi terhadap keberadaan pari- } \\
\text { wisata halal Jawa Timur }\end{array}$ \\
\hline $\begin{array}{l}\text { Sarana pen- } \\
\text { dukung } \\
\text { pariwisata halal }\end{array}$ & 0,13 & 4 & 0,52 & $\begin{array}{l}\text { Sarana pendukung pariwisata halal } \\
\text { hotel bersertifikasi syariah ataupun } \\
\text { atraksi wisata ramah muslim belum } \\
\text { tersedia secara optimal di Jawa Timur. } \\
\text { Keberadaan dan pembangunan hotel } \\
\text { masih didominasi oleh hotel konven- } \\
\text { sional serta atraksi wisata khususnya } \\
\text { objek wisata buatan belum secara } \\
\text { spesifik berkonsep syariah }\end{array}$ \\
\hline
\end{tabular}




\begin{tabular}{|c|c|c|c|c|}
\hline $\begin{array}{l}\text { Sumber daya } \\
\text { manusia yang } \\
\text { ahli dalam } \\
\text { bidang pari- } \\
\text { wisata halal }\end{array}$ & 0,08 & 2 & 0,16 & $\begin{array}{l}\text { Sumber daya manusia dibidang pari- } \\
\text { wisata halal masih minim kuantitas } \\
\text { baik di tingkat nasional maupun di } \\
\text { Jawa Timur. Hal ini dikarenakan juru- } \\
\text { san ataupun program studi pariwisa- } \\
\text { ta (baik SMK, diploma, sarjana dan } \\
\text { pascasarjana) belum banyak yang } \\
\text { membahas tentang pariwisata halal } \\
\text { ataupun pariwisata dalam perspektif } \\
\text { Islam. Kajian ilmiah tentang pariwisa- } \\
\text { ta halal masih minim, padahal san- } \\
\text { gat dibutuhkan untuk perancangan } \\
\text { staregi pengembangan kedepannya. }\end{array}$ \\
\hline $\begin{array}{l}\text { SUB TOTAL AN- } \\
\text { CAMAN }\end{array}$ & 0.36 & & 1,13 & \\
\hline TOTAL & 1,00 & & 3,50 & \\
\hline
\end{tabular}

\section{Diagram Analisis SWOT}

Dari perhitungan tersebut dapat disimpulkan total skor EFAS positif. Skor positif tersebut didapatkan dari hasil penjumlahan antara peluang dengan ancaman dalam pengembangan pariwisata halal Jawa Timur yaitu EFAS $=1,88-1,04=0,84$ (POSITIF). Total skor IFAS yang dihasilkan dari kekuatan dan kelemahan dalam pengembangan pariwisata halal Jawa Timur juga positif. Hasil perhitungan tersebut diperoleh dari penjumlahan antara kekuatan dengan kelemahan yaitu IFAS = 2,37-1,13 = 1,24 (POSITIF). Skor EFAS dan IFAS sama-sama menunjukkan nilai positif. Nilai positif tersebut lebih condong pada kekuatan yang dimiliki dan peluang yang sangat tersedia dalam pengembangan pariwisata halal Jawa Timur. Posisi skor positif tersebut menunjukkan bahwa potensi pengembangan pariwisata halal Jawa Timur berada pada posisi kuadran I.

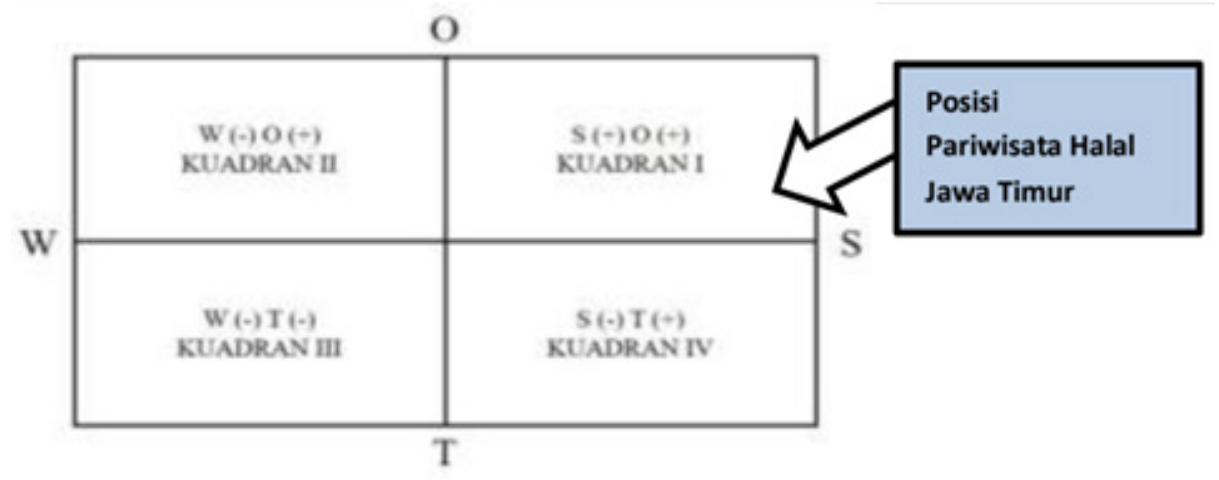

Gambar 2. Kuadran SWOT Pariwisata Halal Jawa Timur

Posisi ini menandakan bahwa pengembangan pariwisata halal di Jawa Timur sangat kuat dan berpeluang, Rekomendasi strategi yang diberikan adalah Progresif, artinya potensi pariwisata halal di Jawa Timur sangat dimungkinkan untuk dikembangkan menjadi salah satu strategi dalam pelengkap sektor pariwisata yang sudah eksis serta menjadi penopang dalam peningkatan PDRB sektor pariwisata di Provinsi Jawa Timur. 
Implikasi dari rekomendasi strategi ini akan menciptakan citra Provinsi Jawa Timur sebagai pengembang pariwisata halal kelas dunia dan mendorong percepatan Indonesia sebagai kiblat pariwisata halal dunia.

Tabel 4. Matrix SWOT

\begin{tabular}{|c|c|c|}
\hline IFAS & $\begin{array}{l}\text { Kekuatan/Strengths (S) } \\
\text { 1. Keberagaman daer- } \\
\text { ah tujuan wisata di } \\
\text { Jatim } \\
\text { 2. Prasarana penunjang } \\
\text { mobilitas wisatawan } \\
\text { Jatim } \\
\text { 3. Tingkat kunjungan } \\
\text { wisatawan di Jatim }\end{array}$ & $\begin{array}{l}\text { Kelemahan/Weak- } \\
\text { ness }(\mathrm{W}) 1 . \text { SDM } \\
\text { yang ahli dalam } \\
\text { bidang pariwisata } \\
\text { halal } \\
\text { 2. Sarana pendukung } \\
\text { pariwisata halal } \\
\text { 3. Promosi dan } \\
\text { branding pari- } \\
\text { wisata halal } \\
\text { Jatim }\end{array}$ \\
\hline $\begin{array}{l}\text { Peluang/Opportunites } \\
\text { (O) } \\
\text { 1. Dukungan kebijakan } \\
\text { pemerintah pusat dan } \\
\text { daerah } \\
\text { 2. Keberadaan lembaga } \\
\text { sertifikasi halal/syariah } \\
\text { untuk sarana } \\
\text { penunjang pariwisata } \\
\text { halal } \\
\text { 3. Reputasi pariwisata } \\
\text { halal } \\
\text { Indonesia ditingkat inter- } \\
\text { nasional }\end{array}$ & $\begin{array}{l}\text { Strategi S-O } \\
\text { Mendorong } \\
\text { investasi dalam } \\
\text { pengembangan } \\
\text { sarana } \\
\text { pendukung pariwisata } \\
\text { halal Jawa Rimur }\end{array}$ & $\begin{array}{l}\text { Strategi W-O } \\
\text { Pengembangan } \\
\text { Multiplatform Infor- } \\
\text { masi } \\
\text { Pariwisata Halal } \\
\text { Jawa Timur ber- } \\
\text { basis Internet of } \\
\text { Things (loT) }\end{array}$ \\
\hline $\begin{array}{l}\text { Ancaman/Threats (T) } \\
\text { 1.Stabilitas ekonomi } \\
\text { daerah, nasional, re- } \\
\text { gional, internasional } \\
\text { dan global } \\
\text { 2.Stabilitas keman- } \\
\text { an dalam dan luar } \\
\text { negeri } \\
\text { 3.Persaingan antar } \\
\text { daerah dan negara } \\
\text { dalam pengemban- } \\
\text { gan pariwisata halal }\end{array}$ & $\begin{array}{l}\text { Strategi S-T } \\
\text { Membangun branding } \\
\text { pariwisata halal Jawa } \\
\text { Timur bertajuk } \\
\text { "Khazanah Jawa Timur" }\end{array}$ & $\begin{array}{l}\text { Strategi W-T } \\
\text { Pengembangan } \\
\text { Kawasan Ekonomi } \\
\text { Khusus Pariwisa- } \\
\text { ta Halal Provinsi } \\
\text { Jawa Timur }\end{array}$ \\
\hline
\end{tabular}

Deskripsi Rumusan Strategi Pengembangan Pariwisata Halal Jawa Timur IV.3.1 Strategi $S-O$ : Mendorong investasi dalam pengembangan sarana pendukung pariwisata halal Jawa Timur

Pengembangan pariwisata halal Jawa Timur membutuhkan investasi yang besar khususnya dalam hal pembangunan sarana penunjang kegiatan berwisata turis muslim. Investasi tersebut dapat berasal dari investasi domestik dan asing. Badan Koordinasi Penanaman Modal (BKPM) mencatat selama lima tahun terakhir, investasi di sektor pariwisata mencapai Rp51,2 triliun. Pada tahun 2016, BKPM mencatat realisasi investasi sektor pariwisata mencapai Rp15 triliun yang terdiri dari investasi dalam negeri sebesar Rp2,2 triliun, sedangkan investasi asing sebesar Rp12,8 triliun. Berikut adalah investasi yang diperlukan dalam pengem- 
bangan sektor pariwisata halal Jawa Timur antara lain :

a. Hotel bersertifikat Syariah: Potensi investasi domestik dan asing dapat dimanfaatkan untuk pembangunan hotel syariah (bersertifikat MUI) berbintang di Jawa Timur. Pembangunan hotel syariah tersebut dapat dilakukan di daerah daerah yang memiliki objek wisata religi seperti Gresik, Pulau Madura, Tuban, dan Pasuruan. Pembangunan hotel syariah berbintang juga diperlukan di Kota Batu, Kota Malang, Kabupaten Banyuwangi, Kabupaten Jember untuk keperluan akomodasi wisatawan yang ingin berwisata budaya atau berkunjung ke objek wisata buatan. Pengembangan hotel syariah akan menunjang aktivitas wisatawan muslim dan dapat menambah kuantitas hotel syariah bersetifikat MUI. Selain itu, PMA dan PMD juga juga dapat dimanfaatkan untuk pembangunan gedung petemuan untuk penyelanggaraan kegiatan Meeting, Incentive, Convention, and Exhibition khusus kegiatan islami.

b. Investasi Wahana Rekreasi Wisata Ramah Muslim: Penetapan Jawa Timur sebagai destinasi wisata halal unggulan membutuhkan pembanguan infrastruktur yang menunjang atraksi wisata di daerah tersebut. Pembangunan infrastruktur tersebut difokuskan pada pembangunan wahana atraksi wisata ramah muslim di Pulau Madura. Berbagai peluang investasi wahana rekreasi yang dapat dibangun antara lain: 1) pembangunan museum modern sejarah peradaban islam nusantara; 2 ) pengembangan pantai dan wahana permainan air (water park) ramah muslim (pengunjung wanita menggunakan burkni, pantai dan kolam air terpisah antar wanita dan pria) yang dilengkapi dengan sarana ibadah yang memadai; 4) pembangunan wahana permainan indoor yang bertemakan sejarah peradaban islam dunia yang menjadi fokus pengembangan pariwisata halal Indonesia.

c. Investasi PMA dan PMDN dalam upaya percepatan pembangunan terminal 3 Bandara Internasional Juanda Jawa Timur. Terminal 3 Bandara Internasional Juanda dapat dirancang dengan konsep bandara ramah muslim kelas dunia, sehingga maskapai asing khususnya dari Timur Tengah tertarik untuk membuka rute penerbangan langsung dari dan ke Surabaya.

\section{Strategi W-O: Pengembangan Multiplatform Informasi Pariwisata Halal Jawa Timur berbasis Internet of Things (IoT)}

Pemanfaatan perkembangan Internet of Things (IOT) kini menjadi sarana bagi wisatawan dalam mencari informasi seputar destinasi wisata sebelum berkunjung. Berdasarkan survei BuzzCity Tahun 2016, media sosial dan internet menjadi preferensi utama sebelum melakukan kunjungan wisata. Hasil survey tersebut menunjukkan bahwa $45 \%$ responden mencari informasi perjalanan secara online. Hal serupa juga diungkapkan dalam hasil penelitian Sari dan Anita (2013), yang menjelaskan bahwa informasi melalui internet berpengaruh terhadap motivasi penggemar traveling berkunjung ke suatu destinasi wisata. Salah satu pengembangan sistem informasi di Jawa Timur untuk mendorong pariwisata halal adalah "Khazanah Madura Berbasis Multiflatform", yaitu :

a. Official Website "khazanah.jawatimur.travel"

Official website dirancang untuk mempromosikan potensi pariwisata halal Pulau Madura. Website ini menawarkan tagline "Khazanah Jawa Timur" yang dintegrasikan dari brand "Wonderful Indonesia". Nama domain official website ini adalah "khazanah.jawatimur. travel". Official website "khazanah.jawatimur.travel" dibuat dengan konsep user friendly dan real time, sehingga memudahkan wisatawan muslim dalam mencari informasi untuk merencanakan perjalanan wisata halal di Jawa Timur mulai dari pilihan daerah yang akan dikunjungi, keberadaan objek wisata religi, festival religi, hotel, transportasi, kuliner dan layanan pendukung lainnya.

\section{b. Official Media Sosial}

Sosial media melengkapi official website yang sudah ada. Media sosial yang digunakan antara lain fanpage facebook, twitter, Line@App, YouTube dan instagram. Konten-konten yang dimuat dalam official media sosial Khazanah Jawa Timur adalah foto, video dan artikel. 
Selain itu terdapat pula info-infor seputar event pariwisata yang sedang dan akan diselenggarakan di Jawa Timur. Strategi untuk menambah pengikut (followers), official media sosial Khazanah Jawa Timur akan mengadakan kompetisi seperti InstaMadura (kompetisi foto dan video singkat tentang pesona wisata halal Pulau Madura), Khazanahh Vlog (kompetisi video blogger bagi Youtuber dengan tema "Assalamualaikum Jawa Timur"), serta lomba artikel yang dimuat di fanpage facebook dan offcial website yang disertai foto pengalaman wisatawan selama berkunjung di Jawa Timur.

\section{c. Aplikasi Khazanah Jawa Timur}

Aplikasi Khazanah Jawa Timur merupakan aplikasi personal travel guide yang bertujuan membantu wisatawan untuk mencari dan menjelajahi potensi pariwisata halal Jawa Timur. Aplikasi ini dirancang dengan konsep user interface yang user friendly sehingga mudah digunakan. Aplikasi Khazanah Jawa Timur akan berbasis HTML5 dikembangkan untuk smartphone Android dan iOS. Aplikasi ini akan dilengkapi fitur-fitur yang lebih lengkap seperti pengingat waktu ibadah dan info tempat ibadah terdekat. Aplikasi ini juga akan diintegrasikan dengan google map untuk memandu wisatawan ketika akan berkunjung ke salah satu objek wisata atau tempat-tempat menarik lainnya selama berwisata di Jawa Timur.

\section{Strategi S-T: Membangun branding pariwisata halal Jawa Timur bertajuk "Khaz- anah Jawa Timur"}

"Khazanah Jawa Timur" mencerminkan segala potensi keindahan Provinsi Jawa Timur yang bisa dinikmati oleh wisatawan khususnya wisatawan muslim dan Jawa Timur sebagai destinasi wisata ramah muslim. Perancangan brandin "Khazanah Jawa Timur" akan menciptakan diversifikasi pariwisata yang ada di Jawa Timur. Branding "Khazanah Jawa Timur" akan melengkapi branding pariwisata yang sudah dibuat sebelunnya oleh pemerintah kabupaten kota di Jawa Timur. Branding ini juga sebagai bentuk identitas Provinsi Jawa Timur sebagai wisata halal yang ramah muslim. Tujuan dari pengembangan Branding "Khazanah Jawa Timur adalah sebagai bentuk promosi pariwisata halal ke Jawa Timur sehingga menarik minat wisatawan khususnya wisatawan domestik dan mancanegara muslim untuk berkunjung. Branding "Khazanah Jawa Timur" akan dirangkai dengan penyelenggaraan event islami kelas dunia yang menampilkan kebudayaan Islam nusantara. Penyelenggaraan berbagai event islami akan menjadi bulan kunjungan di Provinsi Jawa Timur. Berikut beberapa contoh event islami yang dapat diselenggarakan untuk menarik kunjungan wisatawan muslim antara lain :

a. "Festival Pesona Madura": Festival ini bertujuan untuk mengenalkan Pulau Madura sebagi destinasi wisata halal unggulan Indonesia. Berbagai kegiatan dalam festival tersebut antara lain: pementasan budaya dari masyarakat lokal Pulau Madura, bazar produk cinderamata UKM dan kuliner Halal khas Pulau Madura, pagelaran kebudayaan Karapan Sapi dan lain-lain.

b. Musabaqah Tilawatil Qur'an Tingkat Internasional: Merupakan kompetisi tahunan yang akan diselenggarakan oleh pemeirntah pusat dengan menggandeng berbagai pihak seperti pemerintah daerah, akademisi dan pelaku industri pariwisata. Kompetisi ini akan mengundang peserta dari berbagai negara sahabat khususnya yang tergabung dalam OKI (Organisasi Kerja Sama Islam).

c. Indonesia Muslim Fashion Wee : merupakan gagasan pagelaran busana muslim terbesardi dunia. Event ini akan dapat diselenggarakan atas kerjasama kementerian seperti Kementerian Perdagangan, Kementerian Pariwisata, Kementerian Koperasi dan UKM dengan menggandeng sponsorship dari swasta. Indonesia Muslim Fashion Week bertujuan untuk mengenalkan dan mempromosikan brand fesyen muslim lokal kepada pengunjung baik dalam negeri maupun luar negeri. Event ini diharapankan akan menarik minat masyarakat dunia untuk berkunjung ke Jawa Timur dan menjadi potential buyers untuk produk produk fesyen muslim made in Indonesia. Selain itu, Indonesia Muslim Fashion Week juga dapat menjadi wadah bagi perancang busana muslim lokal untuk menunjukkan eksistensi di industri fesyen muslim Jawa Timur baik didalam maupun diluar negeri.

d. Menjadi tuan rumah dalam ajang olahraga multinasional yang melibatkan para atlet dari negara-negara anggota Organisasi Kerja Sama Islam yaitu Islamic Solidarity Games. Penye- 
lenggaraan Islamic Solidarity Games dapat berlangsung di Malang Raya (Kota Malang, Kota Batu dan Kabupaten Malang) dan Kota Surabaya.

e. Promosi Keberadaan Upacara Keagaman (Budaya Islam) di level internasional: Keberagaman budaya Pulau Madura sudah menjadi magnet tersendiri bagi wisatawan dan menjadi salah satu alasan untuk berkunjung. Masyarakat muslim Pulau Madura sering menyelenggarakan berbagai macam upacara adat saat hari kebesaran islam seperti perayaan Maulid Nabi, Muharram serta hari raya Idul Fitri dan Idul Adha.

f. Penyelenggaraan Meeting, Incentive, Convention, and Exhibition dibidang:

a. Pendidikan: Penyelenggaraan seminar internasional di perguruan tinggi khususnya yang mengkaji beragam keilmuan dalam perspektif Islam.

b. Industri: penyelenggaraan Halal Business dnd Insdustry Show di kota-kota besar Jawa Timur akan mendatangkan business treveler di seluruh dunia khususnya dari negara-negara muslim.

\section{Jawa Timur \\ Strategi W-T: Pengembangan Kawasan Ekonomi Khusus Pariwisata Halal Provinsi}

Pembentukan Kawasan Ekonomi Khusus Pariwisata Halal merupakan upaya dalam rangka mempercepat pencapaian pembangunan pariwisata nasional. Kawasan ini akan memiliki keunggulan ekonomi dan geostrategi dalam menarik investor. Kawasan Ekonomi Khusus Pariwisata Halal dipersiapkan untuk memaksimalkan kegiatan-kegiatan pariwisata halal yang ditunjang oleh tumbuh kembang industri kreatif halal dan syariah. Pengembangan KEK Pariwisata Halal akan mendorong Jawa Timur sebagai model pengembangan kawasan untuk pertumbuhan ekonomi syariah yang terintegrasi seperti industri pariwisata, industri kreatif dan industri keuangan. Sebagai contoh, pembentukan KEK Pariwisata Halal Jawa Timur dapat diwujudkan di Pulau Madura.

Pulau Madura merupakan pulau terbesar di Jawa Timur yang dibagi menjadi empat kabupaten yaitu Kabupaten Bangkalan, Kabupaten Sumenep, Kabupaten Sampang dan Kabupaten Pamekasan. Pemerintah Provinsi Jawa Timur telah memproyeksikan Pulau Madura sebagai salah satu destinasi pariwisata halal unggulan Indonesia. Proyeksi tersebut didasakan pada faktor-faktor antara lain: 1) Dominasi populasi muslim di pulau Madura, yang mana Suku Madura yang menjadi mayoritas adalah bergama islam; 2) Keragaman budaya, Pulau Madura dikenal sebagai sebagai salah satu daerah yang kental dengan kebudayaan muslimnya. Sejarah perkembangan islam di Jawa Timur juga terpusat di Pulau Madura; 3) Keberadaan objek wisata religi mulai bangunan masjid bersejarah serta tempat ziarah tokoh-tokoh penyebar muslim di Madura yang banyak dikunjungi oleh wisatawan lokal. Selain itu terdapat juga objek wisata alam seperti pantai, permandian, serta penyelenggaraan festival budaya rutin seperti karapan sapi; 4) aksesibilitas ke Pulau Madura yang bisa ditempuh dengan perjalanan darat dan laut serta saat ini pemerintah sedang mengembangkan bandara di Pulau Madura; 5) Pulau Madura khususnya Kabupaten Bangkalan merupakan bagian dari Gerbangkertosusila (akronim dari Gresik-Bangkalan-Mojokerto-Surabaya-Sidoarjo-Lamongan) yang menjadi kawasan metropolitan di Provinsi Jawa Timur.

Kawasan Ekonomi Khusus Pariwisata Halal nantinya juga didukung oleh keberadaan Badan Otorita Pengelola Pariwisata Halal. Keberadaan badan otorita tersebut dapat mengelola dan mengembangkan kawasan pariwisata halal di Jawa Timur menjadi lebih efektif, terarah efisien dan terkoordinasi. Pembentukan badan tesebut untuk mengsinergikan pemerintah kabupaten kota Jawa Timur agar se-visi dan misi dalam mengembangkan pariwisata halal menuju world class halal tourism. Kewenangan Badan Otorita Pengelola Pariwisata Halal Jawa Timur yaitu memberikan sertifikasi halal pada infrastruktur pendukung pariwisata malalui kerjsama dengan DSN, berkoordinasi dengan swasta dalam pembangunan infrastruktur pariwisata halal seperti hotel syariah melalui skema private public partnership.

Struktur Badan Otorita Pengelolaan Pariwisata Halal Jawa Timur akan serupa dengan badan otoritas sejenis yang sudah ditetapkan oleh pemerintah. Struktur tersebut terdiri dari dewan pengarah dan badan pelaksana. Yang menjadi pembeda adalah keberadaan anggota 
dewan pengarah yaitu berasal dari lembaga Kementerian Agama Dewan Syariah Nasional. Struktur Badan Otorita Pengelolaan Pariwisata Halal Jawa Timur juga akan menggandeng lembaga pendidikan tinggi yang memiliki pusat studi halal serta aparat keamanan negara. Berikut adalah bentuk sinergitas Badan Otorita Pengelolaan Pariwisata Halal Jawa Timur dengan beberapa stakeholders:

a. Badan Otorita Pengelolaan Pariwisata Halal Jawa Timur dengan Lembaga Pendidikan adalah menciptakan sumber daya manusia pariwisata halal yang profesional. Badan Otorita dan perguruan tinggi dapat merumuskan program studi khusus pariwisata halal atau mengintegrasikan pariwisata halal kedalam kurikulum pendidikan yang dapat dikaji dari berbagai disiplin ilmu. Selain itu, hasil kerjasama ini juga menghasilkan publikasi ilmiah tentang pariwisata halal sehingga berkontribusi dalam keilmuan.

b. Badan Otorita Pengelolaan Pariwisata Halal Jawa Timur dengan aparat keamanan seperti Institusi Kepolisian dan atau TNI untuk menjaga keamanan daerah tujuan wisata halal agar senantiasa kondusif.

\section{Kesimpulan Dan Saran}

Pengembangan pariwisata halal Jawa Timur merupakan salah satu strategi dalam menjadikan sektor pariwisata sebagai mesin penggerak perekonomian Jawa Timur. Pengembangan pariwisata halal Jawa Timur didukung oleh potensi seperti kearifan lokal yang berkembang dan dipengaruhi oleh agama Islam, keberadaan objek wisata religi, alam dan buatan serta aksesibilitas dan fasilitas pendukung lainnya. Berdasarkan hasil analisis diagram SWOT, pariwisata halal Jawa Timur berada pada diagram 1 yang artinya sangat berpotensi untuk dikembangkan.

Pengembangan pariwisata halal Jawa Timur memerlukan beberapa strategi, antara lain : 1) mendorong investasi domestik dan asing dalam pengembangan pariwisata halal di Jawa Timur; 2) pengembangan multiplatform pusat informasi pariwisata halal Jawa Timur berbasis IoT; 3) perancangan branding bertajuk "Khazanah Jawa Timur" yang dirangkaikan dengan penyelenggaraan event-event islami kelas dunia yang menampilkan kebudayaan islam nusantara; 4) pembentukan kawasan ekonomi khusus pariwisata halal Jawa Timur. Pengembangan strategi

strategi tersebut, diharapkan dapat mengoptimalkan potensi pariwisata halal Jawa Timur agar menjadi salah sebagai salah satu destinasi pariwisata halal unggulan di Indonesia yang dapat bersaing dengan negara-negara di dunia. Selain itu, eksistensi pariwisata halal Jawa Timur akan mendukung percepatan Indonesia sebagai kiblat pariwisata halal dunia.

\section{Daftar Pustaka}

Alim, Haidar Tsany et al. 2014. Analisis Potensi Pariwisata Syariah Dengan Mengoptimalkan Industri Kreatif Di Jawa Tengah dan Yogyakarta, http://eprints.undip.ac.id/45828/1/ Artikel.pdf

Andi. 2017. 2018, Pasuruan Fokus Kembangkan Wisata Halal, http://travel.kompas.com/ read/2016/04/11/172500627/2018.Pasuruan.Fok us.Kembangkan.Wisata.Halal

Andriani, Dini. 2015. Kajian Pengembangan Wisata Syariah. Kementerian Pariwisata : Jakarta

Arby, Ikhsan. 2012. Mengapa ada Fakultas Pariwisata di UMSB?. (online) https://www.academia.edu/5841658/Wisata_Syariah_Halal_Tourism

Artik, Andi. 2016. Awal Tahun 2017, Kota Malang Targetkan Jadi Destinasi Wisata Halal, http://travel.kompas.com/read/2016/09/01/211500927/Awal.Tahun.2017.K ota. Malang.Targetkan.Jadi.Destinasi.Wisata.Halal

Astutik, Kurnia Fami dan Sarmini. 2014. Budaya Kerapan Sapi Sebagai Modal Sosial Masyarakat Madura Di Kecamatan Sepulu Kabupaten Bangkalan. Jurnal Kajian Moral dan Kewar ganegaraan Nomor 1 Volume 3 
Ayungingtyas, Risk Aprilia D dan Sri Haidayati Djoeffan. 2017. Strategi Pengembangan Pariwisata di Sepanjang Sungai Kapuas Kota Pontianak. Jurnal Perencanaan Wilayah dan Kota, Vol 10 No 1, hal. 4

Badan Koordinasi Penanaman Modal. 2017. Gelar RIF 2017, BKPM Fokus Tingkatkan Investasi Pariwisata dan Infrastruktur Pendukung,

http://www2.bkpm.go.id/images/uploads/file_siaran_pers/Siaran_Pers_BKP M_1702017_Gelar_RIF\%2C_BKPM_Fokus_Tingkatkan_Investasi_Pariwisata.p df,

Badan Perencanaan Pembangunan Daerah Provinsi Jawa Timur. 2015. Buku Data Dinamis Provinsi Jawa Timur. BAPPEDA Jawa Timur : Surabaya

Badan Perencanaan Pembangunan Nasional RI. 2015. Seri Analisis Pembangunan Wilayah : Provinsi Jawa Timur, http://simreg.bappenas.go.id/document/Publikasi/DokPub/05.\%20Analisis\% 20Provinsi\%20Jawa\%20Timur\%202015_ok.pdf

Badan Pusat Statistik. 2016. Jumlah Kedatangan Wisatawan Mancanegara dan Domestik. BPS : Jakarta

Badan Pusat Statistik Provinsi Jawa Timur. 2013. Perkembangan Pariwisata Jawa Timur, https://jatim.bps.go.id/4dm!n/brs_ind/brsInd-20131201024220.pdf

Badan Pusat Statistik Provinsi Jawa Timur. 2017. Pertumbuhan Ekonomi Jawa Timur Tahun 2016, https://jatim.bps.go.id/4dm!n/brs_ind/brslnd 20170213080331.pdf

Chookaew, S et al. 2015. Increasing Halal Tourism Potential at Andaman Gulf in. Journal of Economics, Business and Management, Vol 3 No 7 Hal. 277-279.

BuzzCity. 2016. The BuzzCity Report : A Quarterly Briefing On The Mobile Internet, http:// www.buzzcity.com/l/reports/The-BuzzCity-Report-Vol-6-Issue-2.pdf

DetikNews. 2017. Travel Warning AS ke Jatim, Bupati Anas: Banyuwangi Aman untuk Dikun jungi, https://news.detik.com/berita-jawa-timur/d-2796788/travel warning-as-ke-ja tim-bupati-anas-banyuwangi-aman-untuk-dikunjungi

Fakultas Ilmu Administrasi. 2016. Buku Pedoman Akademik Tahun Ajaran 2016/2017. FIA UB : Malang

Fakultas Vokasi Univeristas Airlangga. 2016. Tentang Program Studi D3 Kepariwisataan, , http://www.unair.ac.id/site/article/read/107/d3- kepariwisataan.html

Ghofar, Abdul. 1999. Analsis Implikasi Pemikiran dan Penafsiran Akuntansi dari Paradigma Mainstream Barat dan Paradigma Islam dalam Kerangka Analisis Konsep TAO (Stu di Kualitatif Komparatif Akuntansi Mainstream dan Akuntansi Alternatif dalam Pem bentukan Akuntansi Humanis. Skripsi (S1). Jurusan Akuntansi, Fakultas Ekonomi, Uni versitas Brawijaya, Malang

Hasan, Ali. 2013. Marketing Dan Kasus-Kasus Pilihan. Yogyakarta: Caps Ismayanti. 2010. Pen gantar Pariwisata. Jakarta: PT Gramedia Widisarana Istijanto . 2006. Riset Sumber Daya Manusia. Jakarta : PT. Gramedia Pustaka Utama

Ismayanti. 2010. Pengantar Pariwisata. Jakarta: PT Gramedia Widisarana Indonesia

Kelana, Irwan. 2015. Hotel Syariah Terkendala Investasi, http://www.republika.co.id/berita/ koran/ syariah koran/15/01/09/nhwmgm5-hotel-syariah-terkendala-investasi

Lembayun, Dika Eka. 2012. Perancangan Kawasan Wisata Pantai di Kabupaten Gresi. Tesis Ditertibkan. Pascasarjana UIN Maulana Malik Ibhrain : Malang

Malhotra, Naresh K. 2015. Essentials of Marketing Research : A Hands-On Orientation. United Kingdom : Pearson Education Ltd

Malhotra, Naresh K dan David F. Briks. 2006. Marketing Research : An Applied Approach. Unit ed Kingdom : Pearson Education Ltd 
Mardiana, Citra Fitri. 2017. Pulau Madura Bakal Punya Wisata Berbasis Syariah, https://finance.detik.com/berita-ekonomi-bisnis/3580526/pulau-madura bakal-punya-wisata-berbasis-syariah

MasterCard \& CrescentRating. 2016. Global Muslim Travel Index 2016. CrescentRating Pte. Ltd dan MasterCard Asia Pacific Pte Ltd : Singapore

Moeloeng, Lexy J. 2004. Metodologi Penelitian Kualitatif. PT. Remaja Rosdakarya : Bandung

Martono, Nanang. 2011. Metode Penelitian Kuantitatif. Jakarta: PT Raya Grafindo Persada.

Murwandani, Nunuk Giari. 2007. Arsitektur-Interior Keraton Sumenep Sebagai Wujud Komunikasi Dan Akulturasi Budaya Madura, Cina Dan Belanda. Jurnal DIMENSI INTERIOR, VOL. 5, NO. 2

National Geographic Indonesia. 2016. Indonesia Raih 12 Penghargaan Bergengsi di Ajang The World Halal Tourism Awards 2016, http://nationalgeographic.co.id/berita/2016/12/indonesia-raih-12- penghargaanbergengsi-di-ajang-the-world-halal-tourism-awards-2016

Nizar, Muhammad Afdi. 2015. Pengaruh Pariwisata terhadap Perdagangan Internasional di Indonesia,https://www.kemenkeu.go.id/sites/default/files/Hubungan\%20Par iwisata\%20Dan\%20Perdagangan\%20Internasional.pdf

Prodjo, Wahyu Adityo. 2017. Status Awas Gunung Agung, 5 Negara Perbarui Travel Advice ke Indonesia, http://travel.kompas.com/read/2017/09/25/074100027/status-awas gunung-agung-5-negara-perbarui-travel-advice-ke-indonesia

Rani, Deddy Prasetya Maha. 2014. Pengembangan Potensi Pariwisata Kabupaten Sumenep, Madura, Jawa Timur (Studi Kasus: Pantai Lombang) Jurnal Politik Muda, Vol. 3 No. 3, Agustus-Desember 2014, 412-421. Surabaya: FISIP UNAIR

Ratman, Dadang Rizki. 2016. Pembangunan Destinasi Pariwisata Prioritas 2016 - 2019, http:// www.kemenpar.go.id/userfiles/Paparan\%20- \%20Deputi\%20BPDIP.pdf

Rangkuti, Freddy.2015. Analisis SWOT : Teknik Membedah Kasus Bisnis. Gramedia Pustaka Utama. Jakarta

Rizka, R. 2016. Persepsi Konsumen Tentang Wisata Syariah Dan Pengaruhnya Terhadap Minat Berkunjung. Skripsi (S1). Jurusan Administrasi Bisnis, FISIP, Universitas Lampung, Bandar Lampung

Sari, Yonita Prateka dan F. Anita Herawati. 2013. Pengaruh Terpaan Informasi Melalui Inter net tentang Pariwisata Terhadap Motivasi Penggemar Traveling Berkunjung ke Yogya karta, http://e-journal.uajy.ac.id/4286/

Soebagyo. 2012. Strategi Pengembangan Pariwisata di Indonesia. Jurnal Liquidity Vol 1 No 2, hal 154

Sosilawati et al. 2016. Sinkronisasi Program dan Pembiayaan Pembangunan Jangka Pendek 2018-2020 Keterpaduan Pengembangan Kawasan dengan Infrastruktur PUPR Pulau Jawa, Volume 1. Kementerian Pekerjaan Umum Dan Perumahan Rakyat : Jakarta 
State of The Global Islamic Economy. 2006. State of The Global Islamic Economy Report 2015/16. Thomson Reuters : New York City

Sugiyono. 2013. Metode Penelitian Kuantitatif Kualitatif dan $R \& D$. Bandung : Alfabeta

Syaikh Salim bin 'led al-Hilali. 2005. Syarah Riyadhush Shalihin Jilid 4. Pustaka Imam As-Syafi'i : Jakarta.

Suherlan, Ade. 2015. Persepsi Masyarakat Jakarta Terhadap Islamic Tourism. The Journal of Tauhidinomics Vol. 1 No. 1, hal 62

Tim Penulis Universitas Negeri Malang. 2000. Pedoman Penulisan Karya Ilmiah: Skripsi, Tesis, Disertasi, Laporan Penelitian, Artikel, dan Makalah. Universitas Negeri Malang : Malang

Utama, I Gusti Bagus Rai. 2010. Pariwisata dalam pandangan Islam dan Muslim. Working Paper for Cultural Study. Universitas Dhyana Pura Bali

Zanuardi, Arfian. 2016. Pembangunan Infrastruktur dalam Pengembangan Wilayah Pulau Madura. Tugas Individu. Fakultas Teknik Sipil dan Perencanaan, Institut Teknologi Sepuluh Nopember : Surabaya

World Economic Forum. 2017. The Travel \& Tourism Competitiveness Report 2017. WEF : Geneva

World Muslim Population. 2014. Wolrdwide Moslem Poplation, http://www.muslimpopulation.com/World/

World Tourism Organization (UNWTO). 2016. UNWTO Tourism Highlights 2016 Edition. UNWTO : Madrid.

World Travel \& Tourism Council (WTTC). 2016. Travel and Tourism Economic Impact 2016 World. WTTC : London

Yudananto, Wisnu et al. 2012. Peranan Sektor Pariwisata Terhadap Perekonomian Daerah Di Indonesia (Analisis Interregional Input-output),

http://repository.unpad.ac.id/15054/1/pustaka_unpad_peranan_sektor_pari wisata. pdf

Zuraya, Nadia. 2017. AS dan Australia Keluarkan Travel Warning ke Indonesia, http://www.republika.co.id/berita/internasional/global/17/05/26/oqja6z383 -as-dan-australia-keluarkan-travel-warning-ke-indonesia 